\title{
Pitfalls in DNA extraction from ancient bones found in Brazilian shell-mounds
}

\author{
Daniela Gaeta Arruda* \\ Mario Hideo Hirata** \\ Orlando Cesar de Oliveira Barretto*
}

\begin{abstract}
ARRUDA, D.G.; HIRATA, M.H.; BARRETO, O.C. de O. Pitfalls in DNA extraction from ancient bones found in Brazilian shell-mounds. Revista do Museu de Arqueologia e Etnologia, São Paulo, 17: 461-467, 2007.
\end{abstract}

Resumo: Os autores descrevem suas dificuldades na extração de ácido desoxiribonuclêico (DNA) de ossos encontrados em sambaquis nas praias da ilha de Sta. Carina, SC, Brasil. A presença de ácido húmico, do ácido fúlvico, radicais livres oxidantes e o efeito hidrolítico dos ambientes úmidos degradam o DNA em fragmentos da ordem de 20-30 pares de bases, impedindo qualquer utilização do DNA extraído. Além disso, o ácido húmico e o ácido fúlvico se ligam fortemente ao magnésio, necessário à atividade da Taq-polimerase, impedindo a reação da polimerase em cadeia (PCR). Neste trabalho são discutidos os protocolos utilizados mais eficientes de extração do DNA e de várias condições possíveis de ensaio da PCR.

Palavras-chave: Sambaquis - Ossos antigos - Extração de DNA de ossos antigos - PCR de DNA antigo.

\begin{abstract}
ncient DNA has been discovered in various types of biological material, including ancient bones, mummies, museum skins, amber-preserved insects, and plant fossils. Such DNA has provided precious information related to archaeology, conservation biology, and forensic science (Brown\&Brown 1994; Kolman\&Tuross 2000; Pääbo et al. 2004; Willerslev \& Cooper 2005).
\end{abstract}

(*) Departamento de Psiquiatria da Faculdade de Medicina da Universidade de São Paulo. OCdeOB (ocdobarr@usp.br); DGA (dani25@ig.com.br).

$\left.{ }^{(* *}\right)$ Departamento de Análises Toxicológicas, Faculdade de Ciências Farmacêuticas da Universidade de São Paulo (mhhirata@usp.br).
The advent of techniques for the enzymatic amplification of specific DNA sequences has allowed the collection of genetic data from thousands and even millions of years ago (Kaestle \& Horsburgh 2002; Pusch et al. 2003; Mulligan 2005). However, most such studies have been severely criticised for failing to take measures to prevent the contamination of purportedly ancient DNA by recent material (Pääbo et al. 2004). Therefore, the authenticity of the DNA sequences obtained cannot be verified. Researchers dealing with ancient material, such as preserved bone, face tremendous difficulty in obtaining good DNA samples, since the quality of ancient DNA can be significantly affected by environmental factors. 
In this study, based on our experience in studying the $\mathrm{ABO}$ blood group in ancient bones of indigenous Brazilian peoples, we discuss the problems that can arise during the extraction of DNA from such bones. The skeletons in question were found in sambaquis, which are shell-mounds located on the beaches of the island of Santa Catarina, in the state of Santa Catarina, Brazil, and have been dated to approximately 100 A.D. (Schmitz et al. 1992; Schmitz et al. 1993; Schmitz et al. 1996). The skeletons were found by Röhr et al. (1977) at the archaeological sites Tapera, Laranjeiras I, Laranjeiras II, Pântano do Sul, Cabeçudas, and Armação do Sul (Table 1) (Schmitz et al. 1992; Schmitz et al. 1993; Schmitz et al. 1996).

Access to the bones was kindly afforded by the Instituto Anchietano, São Leopoldo, RS, and the Museu do Homem do Sambaqui in Florianópolis city, SC, where they are very well stored in individual boxes. Circa 212 bone samples from 190 skeletons which were in good conditions were studied from the archaeological sites.

\section{Table 1}

\begin{tabular}{lc}
\hline \multicolumn{2}{c}{ Bone samples from the archaeological sites } \\
\hline Archaeological sites & Sample sizes \\
\hline \hline Tapera & 138 \\
Armação & 8 \\
Cabeçudas & 22 \\
Pântano & 21 \\
Laranjeiras I & 2 \\
Laranjeiras II & 1 \\
\hline
\end{tabular}

The bones were carefully cleaned with $70 \%$ ethanol and submitted to UV irradiation for $10 \mathrm{~min}$ on both sides in order to destroy superficial contaminating DNA. Initially, we attempted to extract the DNA from the trabecular bones, in which remnants of haematopoietic cells should be found. However, the trabecular bones were filled with dirt and roots, and we therefore decided to work with the compact cortical bone. The cortical bone, although presenting fewer nucleated cells, might better protect these cells from environmental contaminants (Hochmeister et al. 1991; Hochmeister et al. 1998). The bones were cut with a circular saw using sterilised saw blades at $150^{\circ} \mathrm{C}$ in an oven, after which they were scraped using a dental drill with a diamond burr (Ramos et al. 1995) in a laminar flow hood. The powder obtained was suspended in buffered extraction solution containing $10 \mathrm{mM}$ TRIS-HCl, pH 8.0, $500 \mathrm{mM}$ EDTA, $100 \mathrm{mM}$ $\mathrm{NaCl}, 10 \% \mathrm{SDS}$, and $50 \mathrm{~mL}$ proteinase $\mathrm{K}(20$ $\mathrm{mg} / \mathrm{ml}$ ), diluted to $50 \mathrm{mg}: 500 \mathrm{~mL}$ of buffer. The tubes were inverted and rotated (15 cycles $/ \mathrm{min}$ ) overnight at $56^{\circ} \mathrm{C}$. The obtained suspension was centrifuged, and the supernatant was saved. The precipitate was then submitted to the same procedure, after which both supernatants were pooled and submitted to further purification steps. In attempts to extract DNA from these samples, various methods were used. Protocols described by Maniatis et al. (1989) and Boom et al. (1991) were employed, as were those involving DNAzol (Gibco BRL, Gaithersburg, MD, USA), the rapid genomic blood DNA amplification kit (Pharmacia Biotech, Piscataway, NJ, USA), Chelex-100 (Bio-Rad, Hercules, CA, USA), and the QIAamp DNA Mini Kit (QIAgen, Valencia, CA, USA) (Alves et al. 2000; Meijer et al. 1992; Cattaneo et al. 1995; Walsh et al. 1991; Yang et al. 1998; Malhi et al. 2003). The best results were obtained with the Maniatis et al. (1989) protocol. In brief, the suspension was added 1:1 to a phenol/chloroform/ isoamylic alcohol mixture (25:24:1), mixed, and centrifuged at $5000 \mathrm{~g}$ for $10 \mathrm{~min}$, after which the DNA obtained was submitted to a further precipitation step. For DNA precipitation, isopropyl alcohol, rather than ethanol, was chosen, as very small DNA molecules, such as those found in the present study, are not efficiently precipitated by ethanol (Maniatis et al. 1989). In addition, as has been the case in most DNA and RNA precipitation protocols (Evans et al. 1998), 3 M sodium acetate $\mathrm{pH} 5.2$, was chosen over $2.5 \mathrm{M}$ ammonium acetate. The DNA precipitate was washed twice with chloroform in order to remove the excess phenol. All subsequent steps were as previously described (Maniatis et al. 1989). 
However, despite all of these precautions, the polymerase chain reactions (PCRs) failed to achieve satisfactory amplification, omitting DNA amplifications of 100 - to 200-bp fragments, which were exactly those we were looking for. These findings led us to suppose the ancient DNA was degraded to very small fragments. This was, in fact, found to be the case, as evidenced by the finding that electrophoresis of the final DNA extract preparation on a $1 \%$ agarose gel revealed a dark band in the 15 . to 30-bp region.

The bones with which we worked were found in wet ground along the shoreline. Reviewing the literature on ancient bones, we found that contaminating humic acid and fulvic acid, both of which are found in wet soil, can inhibit the Taq polymerase, the crucial factor in the PCR (Tsai et al. 1989; Goodyear et al. 1994). Humic and fulvic acid are strong magnesium chelating agents, and it is known that Taq polymerase is magnesium dependent. In addition, humic and fulvic acid are absorbed between $260 \mathrm{~nm}$ and $280 \mathrm{~nm}$ (Tuross et al. 1994), exactly the range in which DNA is absorbed (260 nm), and can alter the results of DNA concentration assays. Powered bone becomes darker in parallel with increasing degrees of contamination with humic substances. In order to prevent PCR inhibition, $2 \%$ bovine serum albumin was added (Herrmann et al. 1994).

In order to compensate for the chelating effect on magnesium, we performed some
PCRs with DNA samples obtained through the use of increasing concentrations (up to $4 \mathrm{mM}$ ) of magnesium chloride, bearing in mind that magnesium concentrations higher than $4 \mathrm{mM}$ inhibit Taq polymerase. However, the results obtained were unsatisfactory.

The primers used were designed to amplify fragments of $128 \mathrm{bp}$ and $200 \mathrm{bp}$ (Franco et al. 1994). However, the extracts were found to be degraded (15-30 bp). Fragments of approximately $300 \mathrm{bp}$ were occasionally found but were not reproduced. Such fragments were likely the result of contamination with bacteria or fungi (Pääbo 1990).

Table 2 displays strategies for optimising PCR amplification. Since humic and fulvic acids chelate magnesium chloride, which is a crucial factor in Taq polymerase activity, various magnesium chloride concentrations were employed (Tsai et al. 1992).

When no PCR products were obtained, primer concentrations were increased, as were nucleotide concentrations. By virtue of increasing the probability that the primers will identify the target sequences in DNA preparations, higher Taq concentrations might be desirable (Fisher et al. 1993). Various DNA sample dilutions were also employed in order to dilute the inhibitors. However, as the DNA in the preparations was found to be degraded or absent, it was decided that undiluted DNA extracts from bones would be used.

In order to improve the results, various procedures were conducted: increasing the number of PCR cycles (Hardy et al. 1994);

Table 2

\begin{tabular}{|c|c|c|}
\hline \multicolumn{3}{|c|}{ Conditions that can be modified in order to optimise PCR (apud Hirata \& Hirata 2000) } \\
\hline Conditions & $\begin{array}{l}\text { In case of absence of } \\
\text { PCR products }\end{array}$ & $\begin{array}{l}\text { In order to avoid } \\
\text { non-specific bands }\end{array}$ \\
\hline $\mathrm{Mg} \mathrm{Cl}_{2}$ concentration* & $\boldsymbol{\uparrow}$ & $\downarrow$ \\
\hline Primers concentration & $\uparrow$ & $\downarrow$ \\
\hline dNTP concentration $* *$ & $\mathbf{4}$ & $\downarrow$ \\
\hline Taq concentration & $\uparrow$ & $\downarrow$ \\
\hline DNA concentration & $\uparrow$ & $\downarrow$ \\
\hline Sample dilution & $\downarrow$ & $\uparrow$ \\
\hline
\end{tabular}

\footnotetext{
${ }^{*} \mathrm{MgCl}_{2}$ : magnesium chloride; ** dNTP: deoxynucleoside triphosphate.
} 
biphasic amplification (Holland et al. 1992; Hummel et al. 1992); partial amplification of the PCR product (Horai et al. 1989); and "heat soak" (Ruano et al. 1992), in which the extracted DNA was heated to $95^{\circ} \mathrm{C}$ for $15 \mathrm{~min}$ in order to improve the denaturation and hybridisation of the double-stranded DNA. This last procedure was employed in all experiments.

It has been frequently observed that oxidative free radicals and the hydrolytic effect of wet environments degrade ancient DNA (Handt et al. 1994; Schwartz et al. 1991; Lindhal et al. 1993, Höss et al. 1996), inducing structural changes in the DNA, thereby leading to poor and irreproducible results. These pitfalls can explain the enormous difficulty in performing the PCR with ancient bones, especially those unearthed from wet soil.

In addition to the role that humic and fulvic acid play in Taq polymerase inhibition, it has recently been shown that other environmental factors can affect the chances of finding DNA. Favourable conditions include low temperatures, dry environment, few micro-organisms (as micro-organisms and their metabolites can destroy DNA), and neutral or slightly alkaline pH (Burger et al. 1999; Lee et al. 1999). Storing DNA samples at temperatures below " $20^{\circ} \mathrm{C}$ can also aid in preserving their integrity (Lindahl et al. 1993; Höss et al. 1996).

In order to ensure the authenticity of amplified DNA of ancient material, it is mandatory to avoid contaminating the DNA, which can greatly jeopardise the experiments and undermine the reliability of the data obtained.

The most important experiment, which could indicate the presence of PCR inhibitors in the bone DNA extracts, was that in which those extracts were mixed 1:1 with leucocyte DNA extracts obtained from volunteers. Other DNA extracts from those same volunteers had previously afforded successful PCRs. In the present experiment, amplification was not achieved, suggesting that Taq polymerase inhibitors were present in the ancient bone DNA extracts, thereby precluding any amplification.

In conclusion, obtaining good DNA preparations from ancient bones depends on a multitude of factors, and various pitfalls can be encountered. These obstacles are primarily attributable to environmental factors, although skilful technicians, proper laboratory techniques employed in the extraction, and the quality of the reagents used are factors which together ensure good results.

\section{Acknowledgements}

We are deeply indebted to the Instituto Anchietano de Pesquisa, São Leopoldo, RS, and to the Museu do Homem do Sambaqui, Florianópolis, SC, for having kindly allowed the access to their fine collection of bones from shell-mounds found in Santa Catarina Island, SC, Brazil. We also thank the FAPESP sponsorship for the grant no. 97/0095-4. 
ARRUDA, D.G.; HIRATA, M.H.; BARRETO, O.C. de O. Pitfalls in DNA extraction from ancient bones found in Brazilian shell-mounds. Revista do Museu de Arqueologia e Etnologia, São Paulo, 17: 461-467, 2007.

\begin{abstract}
The authors report their difficulties in DNA extraction from ancient bones found in shell-mounds of Sta. Catarina Island, SC, Brazil. The presence of humic acid, fulvic acid, free oxidant radicals and the hydrolytic effect of wet environment degrade the DNA to 20 to 30 base pairs, what jeopardizes any further utilization. The humic acid and the fulvic acid chelate magnesium ion necessary to Taq-polymerase activity, inhibiting the polymerase chain reaction (PCR). In this work the most efficient used protocols for DNA extraction, and the several PCR assay conditions are discussed.
\end{abstract}

Keywords: Shell mounds - Ancient bones - DNA extraction of ancient bones - PCR of ancient DNA.

\title{
References
}

ALVES, H.B.

2000 Avaliação de três métodos de extração de DNA de tecido ósseo para identificação humana pós-morte através da análise de marcadores de DNA. São Paulo, 2000. Dissertação de Mestrado - Faculdade de Ciências Farmacêuticas-USP.

BOOM, R.; SOL, C.I.A.; SALIMANS, M.M.M.; JANSEN C.L.; WERTHEIM-VAN DILLEN, P.M.E.; NOORDAAL, J.V.

1991 Rapid and simple method for purification of Nucleic Acids. Journal of Clinical Microbiology, 28 (3): 495-503.

BROWN, T.A.; BROWN, K.A.

1994 Ancient DNA: using molecular biology to explore the past. Bioassays, 16 (10): 719-726.

BURGER, J.; HUMMEL, S.; HERRMANN, B.; HENKE, W.

1999 DNA preservation: A microsatelliteDNA study on ancient skeletal remains. Electrophoresis, 20: 1722-1728.

CATTANEO, C.; SMILLE , D.M.; GELSTHORPE, K.; PICCINI, A.; GELSTHORPE, A.R.; SOKOL, R,I.

1994 A simple method for extracting DNA from old skeletal material. Forensic Science International, 74 (3): 167-174.

EVANS, J.K.; TROILO, P.; LEDWITH, B.J.

1998 Simultaneous purification of RNA and DNA from liver using sodium acetate precipitation. BioTechniques, 24 (3): 416-418.
GOODYEAR, P.D.; BLACK, S.M.

1994 A reliable method for the removal of copurifying PCR inhibitors from ancient DNA. BioTechniques, 16 (2): 232-237.

HANDT, O.; HÖSS, M.; KRINGS, M.; PÄÄBO, S.

1994 Ancient DNA: methodological challenges. Experientia, 50: 524-529.

HERRMANN, B.; HUMMEL, S.

1994 Ancient DNA. New York: Springer-Verlag ed.. HOCHMEISTER, M.N.

1998 PCR analysis of DNA from fresh and decomposed bodies and skeletal remains in medico-legal death investigations. In: Lincoln, P.J.; Thomson, J. (Eds.) Forensic DNA profiling protocols. Methods in molecular biology. Totowa, N.J., Human Press: 9-18.

HOCHMEISTER, M.N.; BUDOWLE, B.; BORER, U.V.; COMEY, C.T.; DIRHOFER, R.

1991 Typing of deoxyribonucleic acid (DNA) extracted from compact bone from human remains. Forensic Science International, 36 (6): 1649-661.

HOLLAND, M.M.; FISHER, D.L.; MITCHELL, L.G.; RODRIQUEZ, W.C.; CANIK, J.J.; MERRIL, C.R.; WEEDN, V.W.

1992 Mitochondrial DNA sequence analysis of human skeletal remains: identification of remains from the Vietnam War. Forensic Science International, 38 (3): 542- 553.

HORAI, S.; HAYASAKA, K.; MURAYAMA, K.; WATE, N.; KOIKE, H.; NAKAI, N.

1989 DNA amplification from ancient human 
skeletal remains and their sequences analysis. Proceedings of the Japan Academy, 65: 229-233.

HÖSS, M.; JARUGA, P.; ZASTAWNY, T.H.; DIZDAROGLU, M.; PÄ̈̈BO, S.

1995 DNA damage and DNA sequence retrieval from ancient tissues. Nucleic Acids Research, 24 (7): 1304-1307.

HUMMEL, S.; NORDSIEK, G.; HERRMANN, B.

1991 Improved efficiency in amplification of ancient DNA and its sequence analysis. Naturwissenschaften, 79: 359-360.

KAESTLE, F.A.; HORSBURGH, K.A.

2002 Ancient DNA in anthropology: methods, application, and ethics. American Journal of Physical Anthropology, supplement 35: 92-130.

KOLMAN, C.J.; TUROSS, N.

2000 Ancient DNA analysis of human populations. American Journal of Physical Anthropology, 111 (1): 5-23.

LINDAHL, T.

1992 Instability and decay of the primary structure of DNA. Nature, 362: 709-715.

MAHLI, R.S.; MORTENSEN, H.M.; ESHLEMAN, J.A.; KEMP, B.M.; LORENZ, J.G.; KAESTLE, F.A.; JOHNSON, J.R.; GORODESKY, C.; SMITH, D.G.

2003 Native American mtDNA prehistory in the American Southwest. American Journal of Physical Anthropology, 120 (2): 108-124.

MANIATIS, T.; FRITSCH, E.F.; SAMBROOK, J.

1989 Molecular Cloning: a Laboratory manual. $2^{\text {nd }}$ ed. New York: Cold Spring Harbor University Press.

MULLIGAN, C.J.

2005 Isolation and analysis of DNA from archaeological, clinical and natural history specimens. Methods in Enzymology, 395:87-103.

PAÄBO, S.; IRWIN, D.M.; WILSON, A.C.

1990 DNA damage promotes jumping between templates during enzymatic amplification. Journal of Biological Chemistry, 265 (8): 4718-4721.

PÄÄBO, S.; POINAR, H.; SERRE, D.; JAENICKEDESPRES, V.; HEBLER, J.; ROHLAND, N.; KUCH, M.; VIGILANT, L.; HOFREITER, M.

2004 Genetic analysis from ancient DNA. Annual Review of Genetics, 38: 645-679.

PUSCH, C.M.; BROGHAMMER, M.; BLIN, N.

2003 Molecular phylogenetics employing modern and naciente DNA. Journal of Applied Genetics, 44 (3):269-290.
RAMOS, M.D.; LALUEZA, C.; GIRBAU, E.; PÉREZ, A.P.; QUEVEDO, S.; TURBÓN, D.; ESTIVILL, X.

1993 Amplifying dinucleotide microsatellite loci from bone and tooth samples of up to 5000 years of age: more inconsistency than usefulness. Human Genetics, 96: 205-212.

RÖHR, J.A.

1977 O sítio arqueológico do Pântano do Sul- SC-F-

10. Florianópolis, Santa Catarina: Imprensa Oficial do Estado de Santa Catarina.

RUANO, G.; PAGLIARO, E.M.; SCHWARTZ, T.R.; LAMY, K.; MESSINA, D.; LEE, H.C.

1993 Heat-soaked PCR: an efficient method for DNA amplification with applications to forensic analysis. Biotechniques, 13: 266-274.

SCHMITZ, P.I.; MASI, M.A.N.; VERARDI, I; JACOBUS, A. ; ROGGE, J.H.

1994 Escavações arqueológicas do Pe. João Alfredo Röhr. O sítio da praia das Laranjeiras II. Uma aldeia da tradição ceramista Itararé. Antropologia ${ }^{\circ} 49$, Instituto Anchietano de Pesquisas.

SCHMITZ, P.I.; VERARDI, I.; BITENCOURT, A.L.V.

1995 Escavações arqueológicas do Pe. João Alfredo Röhr. O sítio arqueológico de Laranjeiras I, S.C.; O sítio arqueológico do Pântano do Sul, S.C.; Cabeçudas: um sítio Itararé no litoral de Santa Catarina; Visão de conjunto dos sítios de Tapera, Armação do Sul, Laranjeiras I e II, Pântano do Sul e Cabeçudas. Antropologia ${ }^{\circ} 53$, Instituto Anchietano de Pesquisas.

SCHMITZ, P.I.; MAIS, M.A.N.; VERARDI, I.: LAVINA, R.; JACOBUS, A.

1992 Escavações arqueológicas do Pe. João Alfredo Röhr. O sítio arqueológico da Armação do Sul. Antropologia n48, Instituto Anchietano de Pesquisas.

SCHWARTZ, T.R.; SCHWARTZ, E.A.; MIESZERSKI,

L.; MCNALLY, L.; KOBILINSKY, L.

1991 Characterization of deoxyribonucleic acid (DNA) obtained from teeth subjected to various environmental conditions. Forensic Science International, 36 (4): 979-990.

TUROSS, N.

1993 The biochemistry of ancient DNA in bone. Experientia, 50: 530- 535.

WALSH, P.S.; METZER, D.A.; HIGUSHI, R. 1990 Chelexò 100 as a medium for simple 
extraction of DNA for PCR-based typing from forensic material. BioTechniques, 10 (4): 506-513.

WILlERSlEV, E.; COOPER, A. 2005 Ancient DNA. Proceedings of Biological Sciences, 272 (1558): 3-16.
YANG, D.Y.; ENG, B.; WAYE, J.S.; DUDAR, J.C.; SAUDERS, S.R.

1988 Technical note: improved DNA extraction from ancient bones using silica-based spin columns. American Journal of Physical Anthropology,105: 539-543.

Recebido para publicação em 5 de outubro de 2007. 